\title{
Ethnobotanical Study of Medicinal Plants in Dodola Town, South Ethiopia
}

\author{
Timar Petros Menbere $^{1^{*}} \quad$ Kelil Hasen $^{2} \quad$ Milkiyas Petros Menbere $^{3}$ \\ 1.Department of Biotechnology, Addis Ababa Science and Technology University, Addis Ababa, Ethiopia \\ 2.Department of Biology, Dilla University, Dilla, Ethiopia \\ 3.Department of Industrial Chemistry, Ariba Minch University, Ariba Minch, Ethiopia
}

\begin{abstract}
Medicinal plant is any plant from which one or more of its organs contain ingredients essential for therapeutic purpose. In Ethiopia, the use of traditional medicines is widely prevalent in the country but ethnobotanical studies on medicinal plants in the country are limited when compared to the multiethnic and cultural diversity of the people and diverse flora of the country. The present study aimed to document the medicinal plant species, identify the plant parts used to treat human disease, assess community perception and identify the threats to medicinal plant conservation in Dodola Town, in Ethiopia. The study focused on three kebeles namely, Geneta, Gedira and Tullo Alawanso based on the recommendations of elders and local authorities. Sixty respondents were selected from these three kebeles and 15 key informants (10 males and 5 females) were added based on the recommendations of local knowledgeable elders, local leaders and development agents. Questionnaire distribution, interviews and focus group discussions were the data collection tools. The result indicated a total of 10 wild medicinal trees and shrubs that were identified useful for treating human disease in Dodola Town. The plants and parts used to treat diseases varied from disease to disease. Leaf, fruit, bark and root were widely used for treating human disease but leaves and roots were the frequently used plant parts. Mostly medicinal plants in the area were used in their fresh form. The study also indicated as the majority of respondents have positive perception towards medicinal plants and their use in the area. The medicinal plants of the town are facing threat from intensification of agriculture, wood extraction and over grazing.
\end{abstract}

Keywords: Dodola, Ethnobotanical study, Medicinal plants.

DOI: $10.7176 / \mathrm{JBAH} / 12-1-04$

Publication date: January $31^{\text {st }} 2022$

\section{Introduction}

Traditional medicine is a medicine that is dependent on locally available plant or animal resources which are easily accessible, simple to use and affordable. This made traditional medicine to be used throughout the world (Awas and Demissew, 2009). Medicinal plant is any plant from which one or more of its organs contain ingredients essential for therapeutic purpose or contain foundation compounds that can be used for synthesis of useful drugs. Thus, plants were making the basis of traditional medicine system in the past and continue to provide these benefits in the future (Balick and Cox, 1996).

In Ethiopian, traditional medicines were used for many centuries and their use has been an integral part of the different cultures in the country (Mesfin et al., 2009). About eighty percent of the people and ninety percent of livestock depend on these traditional medicines (Bekele, 2007). The major share (i.e. more than 95) percent of traditional medicine are obtained from plant origin (Wubetu et al., 2018). Furthermore, the main population living in the rural areas and the poor people in urban areas mainly depends on traditional medicines to meet their primary health care needs (Mesfin et al., 2009).

In Ethiopia, the use of traditional medicines is widely prevalent in the country due to the cultural acceptability, perceived value against certain types of diseases, physical accessibility and affordability (Defar, 1998; Hunde et al., 2006). However, ethnobotanical studies on medicinal plants in the country are limited when compared to the multiethnic and cultural diversity of the people, diverse flora of the country and vital role played by traditional medicinal plants for primary health care (Fullas, 2005). Similarly, little effort has been made so far to document the knowledge base and conserve medicinal plants in the country (Gidey et al., 2009). In most parts of Ethiopia the rich biological diversity and the associated indigenous knowledge of medicinal plants was not sufficiently documented (Maryo et al., 2015; Yineger et al., 2008).

Apart from the incomplete studies made, valuable medicinal plants are declining due to various factors in Ethiopia. Medicinal plants and the associated knowledge are being threatened by ongoing deforestation, environmental degradation, population pressure, agricultural expansion and modernization (Balemie et al., 2004; Bekele, 2007). Equally threatened is the knowledge base on which the traditional medicinal system is based, as the ethnobotanical information is not documented and remains in the memory of elderly practitioners. This shows the need of studying medicinal plants in various parts of the country where little or no ethnobotanical explorations have been made to have detailed information about it (Awas and Demissew, 2009). The Studies and documentations of medicinal plants help to reduce the accelerated ecological destruction and cultural 
transformations that challenge these plants and the culturally held knowledge bases (Bekele, 2007). This necessitates the need to investigate the status of medicinal plant resource and knowledge base associated with it for successful resource conservation and development. Therefore, the present study was initiated to investigate and document the medicinal plant species, identify the plant parts used to treat human disease, assess community perception towards medicinal plants and identify the challenges affecting medicinal plant conservation in Dodola Town, in Ethiopia.

\section{Methodology}

\section{Description of study area}

The study was conducted in Dodola Town which is found in Oromia Regional State of Ethiopia (Fig 1). The Town was selected because it is part of the unique alpine ecosystem with unique plant diversity and cultural associations. The Town is situated $303 \mathrm{kms}$ south east of Addis Ababa, the capital city of Ethiopia. The mean minimum and maximum annual rain fall is $280 \mathrm{~mm}$ and $910 \mathrm{~mm}$, respectively. While the temperature ranges from $12^{\circ} \mathrm{C}$ to $27^{\circ} \mathrm{C}$. The 2007 National census report indicated that the total population of the Dodola Town was 86,754 (Central Statistics Agency, 2007).

\section{Sampling design}

Before the actual ethno-botanical data collection, stake holders such as development agents, local leaders and elders were contacted to locate the appropriate sampling kebeles in the area. Then, three kebeles such as Geneta, Gedira and Tullo Alawanso were randomly selected based on the recommendations of elders and local authorities (Mesfin et al., 2009). Similarly, 60 respondents were selected from these three kebeles based on the recommendation of local elders, local leaders and development agents. In addition, 15 key informants (10 males and 5 females) were selected as recommended by local leaders and knowledgeable elders. Key informants included in the focus group discussion were knowledgeable elders, religious leaders and traditional healers. Involving local leaders, elder people, and development agents is crucial in the ethno-botanical study of medicinal plants in different areas (Maryo et al., 2015).

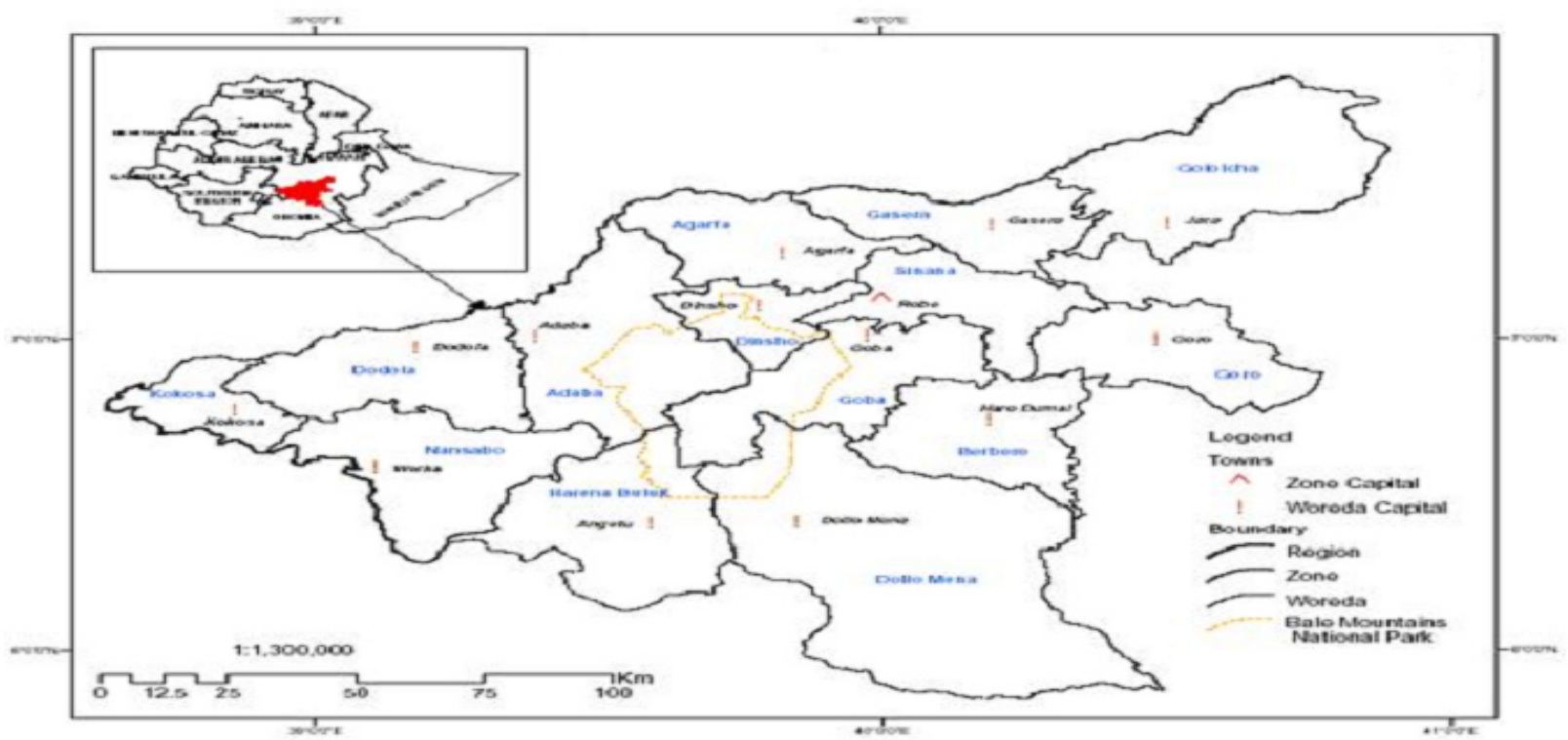

Figure 1. Map of the study area

\section{Method of data collection}

This research was conducted from December 2017 to August 2018. The primary data were collected through questionnaires, interviews and focus group discussions. These methods are important approaches of an ethnobotanical study of medicinal plants (Cotton, 1996). Questionnaires were administered to identify the different medicinal plants and the diseases treated with them, to assess the state of medicinal plants during their application, to assess community perception towards medicinal plants and to identify challenges of medicinal plant conservation in the area. Similarly, interviews were employed to identify the medicinal plants and associated diseases treated by them and to examine community perception towards the species. Discussion with key informants was made to identify the medicinal plant use status, conservation challenge, mode of application, etc. Moreover, different documents were reviewed to support the study.

Questionnaire was administered for the 60 selected respondents from the three kebeles. It was prepared in Afan-Oromo (which is the local knowledge) in the area. In the same manner, interviews were made with 15 
selected knowledgeable local elders, religious leaders and local leaders. During each interview, the aim of the interview was explained first to invoke clear and objective responses by respondents. Then, informants were asked for their consent to provide responses on the questions. During the study period, key informants were asked two to three times in order to confirm the reliability of the ethno-botanical information. In addition, the responses that were not in harmony with each other in both questionnaire and interview data were rejected (Mesfin et al., 2009). A range of ethno-botanical information including plant local names, uses, parts used, mode of utilization, plant habit and habitat, conservation status and existing threats to the plants were covered. Ethnobotanical study of local knowledge can be used as a tool for investigating human perceptions of biodiversity loss and change in abundance and use of plant species through time (Cotton, 1996).

\section{Data analysis}

The quantitative data obtained from questionnaire were analyzed using descriptive statistical method such as percentage. While the qualitative data obtained through interview and focus group discussions were analyzed in the form of descriptions.

\section{Result and discussion}

\section{Socio-demographic characteristics of respondents}

From the 60 respondents who were involved as traditional medicinal plant practitioners in the study area, 40 $(66.67 \%)$ were males whereas $20(33.33 \%)$ were females. The ages of respondents were ranked between 23 and 80. But, the majority $47(78.33 \%)$ were between 40 and 70 and only $13(21.67 \%)$ were below 40 years. The educational level of the respondents was characterized by absence of formal education for many of traditional healers and only $21(35 \%)$ have reached grade 8 .

\section{Medicinal plants, diseases treated and parts used}

A total of 10 wild medicinal plants were identified as being useful for treating human disease in Dodola Town (Table 1). Overall, 6 trees, 2 climbers, 1 shrub and 1 herb species were identified as medicinal plants in the area. The plant parts used to treat human disease varied from disease to disease. Leaf, fruit, bark and root were widely used for treating human disease. Leaves and roots were the frequently used plant parts. This is in line with the study of (Assefa and Abebe, 2014), in Benna Tsemay District, in Southern Ethiopia in which roots and leaves comprised the commonly used parts of medicinal plants in the area. Similarly, leaves are the most widely used plants part for medicinal purposes contributing nearly 50\% of medicinal plants utilized (Awas and Demissew, 2009). Besides, roots, fruits and bark are also important parts of medicinal plants used in fresh and dry forms (Banjaw et al., 2016).

Table 1. List of medicinal plants, diseases treated and condition of the medicinal plant used.

\begin{tabular}{|c|c|c|c|c|c|}
\hline No & Medicinal plants (Family) & ocal name & Habit & Diseases treated & used \\
\hline 1. & $\begin{array}{l}\text { Balanites aegyptiacus (L.) } \\
\text { Delile (Xygophyllaceae) }\end{array}$ & Amata & $\mathrm{T}$ & $\begin{array}{l}\text { Abdominal problems, } \\
\text { Tuberculosis }\end{array}$ & Fruit \\
\hline 2. & $\begin{array}{l}\text { Agave sisalana Perrine ex } \\
\text { Engelm. (Agavaceae) }\end{array}$ & Walensu & $\mathrm{H}$ & Ear disease & Leaf \\
\hline 3. & $\begin{array}{l}\text { Anogeissus leiocarpa (DC.) } \\
\text { Guill. and Perr. (Combretaceae) }\end{array}$ & Hagersu & $\mathrm{T}$ & $\begin{array}{r}\text { Stomach pain, diarrhea, } \\
\text { malaria, wounds }\end{array}$ & Leaf \\
\hline 4. & $\begin{array}{l}\text { Boswellia papyrifera (Del.) } \\
\text { Hochst. [Burseraceae] }\end{array}$ & Ajawa & $\mathrm{T}$ & Diarrhea & Bark \\
\hline 5. & $\begin{array}{l}\text { Bridelia micrantha (Hochst.) } \\
\text { Baill. [Phyllanthaceae] }\end{array}$ & Lafto & $\mathrm{T}$ & Scorpion bite & Bark \\
\hline 6. & $\begin{array}{l}\text { Capparis tomentosa Lam. } \\
\text { [Capparaceae] }\end{array}$ & Altit & $\mathrm{S}$ & $\begin{array}{l}\text { Epilepsy, evil eye, } \\
\text { evil sprit }\end{array}$ & Root \\
\hline 7. & $\begin{array}{l}\text { Cordia Africana Lam. } \\
\text { wounds, gastritis/ }\end{array}$ & Kararu & $\mathrm{T}$ & Broken body/hand, & Leaf [Boraginaceae] \\
\hline 8. & $\begin{array}{l}\text { Croton macrostachyus Hochst. } \\
\text { ex Delile [Euphorbiaceae] }\end{array}$ & Sareti & $\mathrm{T}$ & $\begin{array}{l}\text { constipation } \\
\text { Rabies, spleenomegally, } \\
\text { ovine pasteurellosis, epilepsy, } \\
\text { anti-termite, hyper-blurbia }\end{array}$ & Root \\
\hline 9. & $\begin{array}{l}\text { Cucumis dipsaceus Ehrenb. } \\
\text { [Cucurbitaceae] }\end{array}$ & Keltu & $\mathrm{C}$ & $\begin{array}{l}\text { Snake bite, insecticide, } \\
\text { Stomach pain/diarrhea, } \\
\text { tuberculosis }\end{array}$ & Root \\
\hline 10. & $\begin{array}{l}\text { Cucurbita maxima Duchesne } \\
\text { [Cucurbitaceae] }\end{array}$ & Heexoo & $\mathrm{C}$ & Tape worm & Fruit \\
\hline
\end{tabular}


According to the above table, different disease types were distinguished as human health problems in the study area. Among them stomach pain, tuberculosis, wounds, diarrhea and epilepsy were some of the diseases. These diseases were treated by using more than one medicinal pant and plant part for each disease. This is more alike to the study of (Awas and Demissew, 2009), in which more than one plant is used to treat a particular aliment. Similarly, there also cases where a particular plant is used to treat many aliments. In contrast to this, other diseases in the area were treated using one medicinal plant for each disease. According to (Assefa and Abebe, 2014), sometimes some ailments can be treated by some medicinal plants or a few knowledgeable traditional herbalists unlike the commonly treated diseases. In addition, mental health disorders such as epilepsy, evil eye, evilsprit, are also identified in the area and they were treated by Capparistomentosa and Croton macrostachyus. This is similar to the study of (Wubetu et al., 2018), in which epilepsy and evil eye/Buda are among the common mental health disorders treated by treated by Capparistomentosa and Croton macrostachyus.

\section{The state of medicinal plants during their application}

The state of medicinal plants during their application is given in (Fig 2). Mostly medicinal plants will be ready for use in their fresh form. Drying of medicinal plants is also practiced before they are applied on the aliment. The other approach to use medicinal plants in the area is mixing it with water. This is in line with the study of (Regassa, 2013), in Hawassa Town, in which the conditions of plant part used indicated that majority were used in fresh form while some groups indicated as medicinal plants were used in dried form. Similarly, preserving medicinal plants that they could not find in the dry or rainy season for various reasons were reported by the communities in Hawassa Town (Regassa, 2013). This is due to the presence of different application state of medicinal plants.

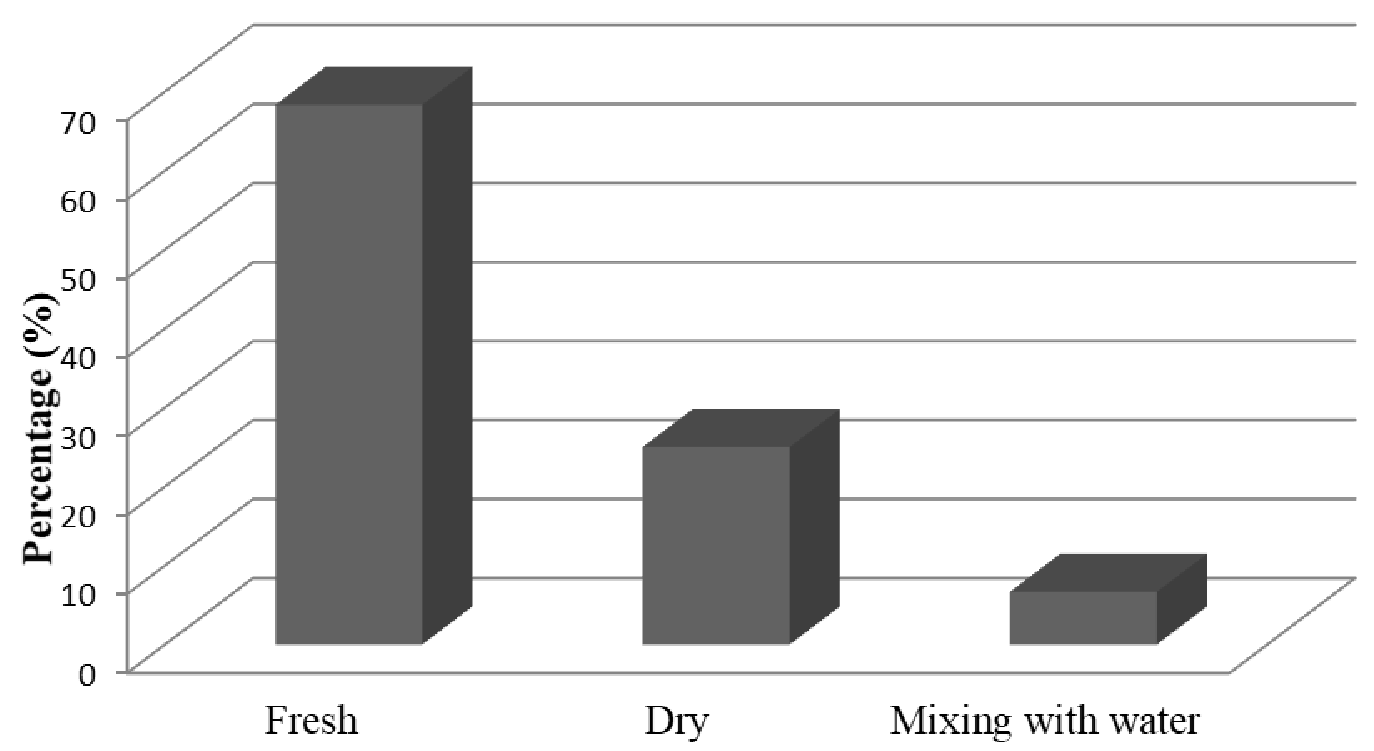

Figure 2. The state of medicinal plants during their application

When we compare the different medicinal plants application state, most were harvested for immediate use. This is similar to the study of (Bassa, 2018), in which freshly prepared and administered medicinal plant species accounted the major share in Wolayita Zone. Less than quarter share indicate as they were prepared and administered after quick drying. Use of medicinal plants mixing with pure water is also practiced in the area (Bassa, 2018). In smilar study in Wondogenet Agricultural Research Center Botanical Garden, (Banjaw et al. 2016), indicated as different parts of medicinal plants are used for primary human health care. Such plants parts harvested and prepared in different herbal fresh, dry and essential oil form for local consumption of the plants.

\section{Perceptions of communities towards medicinal plant use in Dodola Town}

The perception of communities towards medicinal plant use in Dodola Town is given in (Table 2). The majority of respondents have positive perception towards medicinal plants and their use in their local area. This good perception of communities towards medicinal plants and their use is crucial for future conservation of the plants and the related ecosystem (Maryo et al., 2015). 
Table 2. Perceptions towards medicinal plant use in Dodola Town Perceptions

\begin{tabular}{|c|c|c|c|}
\hline \multicolumn{4}{|c|}{ Response } \\
\hline & & & \\
\hline $\mathbf{F}$ & $\%$ & $\mathbf{F}$ & $\%$ \\
\hline
\end{tabular}

Can you mention traditional medicinal plants used in your local area?

\begin{tabular}{lccc}
50 & 83.33 & 10 & 16.67 \\
20 & 33.33 & 40 & 66.67 \\
45 & 75.00 & 15 & 25.00 \\
& & & \\
35 & 58.33 & 25 & 41.67 \\
& & & \\
52 & 86.67 & 8 & 13.33 \\
45 & 75.00 & 15 & 25.00 \\
& & & \\
12 & 20.00 & 48 & 80.00 \\
55 & 91.67 & 5 & 8.33 \\
56 & 93.33 & 4 & 6.67 \\
47 & 78.33 & 13 & 21.67 \\
\hline
\end{tabular}

Are all parts of the plants used for traditional medicine?

Are all medicinal plants curative?

Do you believe that the traditional healers are better than modern medicine?

Are traditional healers and modern medicine equal

interms of their price?

Are all medicinal plants mixed with other ingredients?

Do the traditional medicinal plants have their own

side effects?

Are all people cure with using traditional medicine?

Is the use of traditional medicine dosage clear for users?

Do you suggest peoples go to traditional healers shops?

F: Frequency, \%: Percentage

In the above table, the communities responded as people using traditional medicine are mostly cured from their ailments, the presence of specific dosage for users, the equality of their price with modern medicine, mixing of medicinal plants with other ingredients and the existence of curative ability for medicinal plants that vary with the parts used and others. Perception plays an important role in knowing the potential consumers' attitude and behaviours towards traditional medicines (Salma and Ramakrishnan, 2017). The good perception of community towards medicinal plants is crucial for Dodola and its surroundings that make up one of the important priority forest areas of the country. This in turn supports the natural forest in general and medicinal plants in particular (Asfaw, 2004). If the perception local people towards medicinal plants is poor, it can leads to threats to the knowledge of medicinal plants in the area (Maryo et al., 2015).

\section{Threats to medicinal plant protection in the area}

The main challenges of medicinal plant conservation in Dodola Town include agriculture, wood extraction and over grazing. Fire hazards and drought were also described as the challenges of medicinal plant conservation in the area (Table 3).

Table 3. Threats to medicinal plant protection in the areas

\begin{tabular}{lcc}
\hline & \multicolumn{3}{c}{ Respondents } \\
\cline { 2 - 3 } Threats & $\mathbf{N}$ & $\mathbf{( \% )}$ \\
\hline Agricultural expansion & 27 & 45 \\
Over grazing & 10 & 16.67 \\
Fire hazards & 3 & 5 \\
Drought & 2 & 3.33 \\
Wood extraction including firewood collection & 18 & 30 \\
\hline
\end{tabular}

\section{$\mathrm{N}$ : Number of respondents, \%: Percent}

Due to its varied topography and climate, Ethiopia possesses different plant species that grow on its highland and lowland ecosystems. However, many plant species including medicinally valuable are facing threats due to over and improper exploitation, habitat loss, habitat fragmentation and expansion of urbanization. Especially, agricultural expansion is the main threat to wild plant species (Zenebe, et al., 2012). This affects the health of many communities that are dependent on these plants and their livelihood as well (Banjaw et al., 2016). On the other hand, the increasing global demand for medicinal products accelerated conservation cultivation, and marketing of the plants (Banjaw et al., 2016). Major threats to medicinal plants such as agricultural expansion, wood extraction and overgrazing which were recorded in Dodola Town are likely associated with population increase and shortage of agricultural lands. This has been evidenced in (Kembata Zone), in which intensive farming and wood extraction were more linked with high population pressure and the scarcity of farmland (Maryo et al., 2015). In the same manner, the study made by (Tewelde et al., 2017), on medicinal plants in Laelay Adi-yabo District, in Northern Ethiopia indicated agricultural expansion as the most serious threat to the medicinal plants followed by fire wood collection. Agricultural expansion and deforestation are also the $1^{\text {st }}$ and $2^{\text {nd }}$ threats to medicinal plants in the study conducted in Dire Dawa City Administration (Kebede, et al., 2017). 


\section{Conclusion and recommendation}

Medicinal plant is any plant which contains ingredients essential for therapeutic purpose. In Ethiopia, the use of traditional medicines is widely prevalent but ethnobotanical studies on medicinal plants are limited. The present study indicated the presence of 10 commonly used wild medicinal trees and shrubs useful for treating human disease. The plants and parts used to treat diseases varied from disease to disease. Leaves and roots were the frequently used plant parts. The medicinal plants of the area were mostly used in their fresh form. The perception of communities towards medicinal plant is characterized by positive perception. Despite their different values, medicinal plants of the town are facing growing threats from intensification of agriculture, wood extraction and over grazing. Hence, conservation activities that involve the local people and provision of adequate emphasis for documentation of local medicinal knowledge is vital.

\section{References}

Abebe, D. (1986). Traditional medicine in Ethiopia. The attempt being made to promote it for effective and better utilization. SINET: Ethiop J Sci 1986, 9:61-69.

Addis, G. (1999). Perception of modern and traditional heath practioners about traditional medicine, Arsi zone. Ethio. J health. Pp.16:19-29

Asfaw, S. (2004). Adaba-Dodola Community-based Eco-tourism Development. A report paper. P. 1-14, Austria/Ethiopia.

Assefa, A. and Abebe, T. (2014). Ethnobotanical Study of Wild Medicinal Trees and Shrubs in BennaTsemay District, Southern Ethiopia. Journal of Science \& Development 2(1): 17-33.

Awas, T. and Demissew, S. (2009). Ethnobotanical study of medicinal plants in Kafficho people, southwestern Ethiopia, In: Proceedings of the 16th International Conference of Ethiopian Studies, ed. by Svein Ege, Harald Aspen, Birhanu Teferra and Shiferaw Bekele, Trondheim 2009. Pp. 711-726.

Balick, M.J. and Cox, PA (1996). Plants, people and culture: The science of ethno botany. Scientific America Newyork.USA. pp. 215-229.

Banjaw DT, Dikir W, Gebre A, Geja W, Tsegaye D, et al. (2016) Aromatic and Medicinal Plants in Wondogenet Agricultural Research Center Botanical Garden, South Ethiopia. Med Aromat Plants (Los Angel) 5 (6):1-2. 278. doi: $10.4172 / 2167-0412.1000278$

Bassa, T. (2018). Ethnobotanical Study of Medicinal Plants in Wolaita Zone, Southern Ethiopia. Journal of Health, Medicine and Nursing, 48, 2018, 1-19.

Bekele, E. (2007). Study on actual situation of medicinal plants of Ethiopia. http//www: endashaw.com.

Central Statistics Agency (2007). Central Statistics Agency of Ethiopian, Population Census.

Cotton, C.M. (1996). Ethnobotany: Principles and applications. Chichester, New York: John Wiley and Sons Ltd; 1996.

Cunninghum. A. B. (1992).Wild plant use and resource managements.

Ensermu Kelbessa, (1992).Threatened endemic plants of Ethiopia.

Fullas, F. (2005). The role of indigenous medicinal plants in Ethiopia.

Hamilton. A.C. (2003). Medicinal plants and conservation issue and approaches.

Kebede, A., Ayalew, S., Mesfin, A. and Mulualem, G. (2017). Assessment on the Use, Knowledge and Conservation of Medicinal Plants in Selected Kebeles of Dire Dawa Administration, Eastern Ethiopia. Journal of Plant Sciences, 5, (2): 56-64. doi: 10.11648/j.jps.20170502.12

Maryo, M., Nemomissa, S. and Bekele, T. (2015). An ethnobotanical study of medicinal plants of the Kembatta ethnic group in Enset-based agricultural landscape of Kembatta Tembaro (KT) Zone, Southern Ethiopia. Asian Journal of Plant Science and Research, 2015, 5(7):42-61.

Mesfin, F., Demissew, S. and Teklehaymanot, T. (2009). An ethnobotanical study of medicinal plants in Wonago Woreda, SNNPR, Ethiopia. Journal of Ethnobiology and Ethnomedicine, 2009, 5:28.doi:10.1186/1746-4269-5-28.

Regassa, R. (2013). Assessment of indigenous knowledge of medicinal plant practice and mode of service delivery in Hawassa city, southern Ethiopia. Journal of Medicinal Plants Research, 7(9), pp. 517-535.

Salma, S. and Ramakrishnan, L. (2017). Study on most frequently consumed spices in households and the consumer's knowledge and preferences to organic spices in Coimbatore district, Tamil Nandu, India. International Journal of Herbal Medicine 2017; 5(3): 49-52

Tewelde, F., Mesfin, M. and Tsewene, S (2017). Ethnobotanical Survey of Traditional Medicinal Practices in Laelay Adi-yabo District, Northern Ethiopia. International Journal of Ophthalmology \& Visual Science, 2 , (4): 80-87. doi: 10.11648/j.ijovs.20170204.11

Wubetu, M., Sintayehu, M., Aeta, M. A., Reta, H. and Derebe, D. (2018). Ethnobotany of Medicinal Plants used to Treat Various Mental illnesses in Ethiopia: A Systematic Review. Asian Journal of Plant Science and Research, 2018, 8(1):9-33.

Zenebe,G.,Zerihun, M. and Z. Solomon (2012).An Ethnobotanical Study of Medicinal Plants in Asgede Tsimbila District, Northwestern Tigray, Northern Ethiopia. Ethnobotany Research \& Applications, 10: 305-320. 